Jap. J. M. Sc. \& Biol., 13, 13-22, 1960

\title{
INFLUENCE OF OXYTETRACYCLINE UPON THE TOXIN PRODUCTION OF TYPE E CL. BOTULINUM
}

\author{
GENJI SAKAGUCHI, SUMIKo SAKAGUCHI, TOSHIHARU KAWABATA, \\ YUMIKO NAKAMURA, TAEKO AKANO AND KIMIKO SHIROMIZU \\ Department of Food Control, National Institute of Health, Tokyo
}

(Received: February 24th, 1960)

The antibacterial action of chlortetracycline against vegetative cells and spores of $\mathrm{Cl}$. botulinum type $\mathrm{E}$ in minced fish flesh was investigated by Boyd et al. (1956). Control of type $\mathrm{E}$, fish-borne botulism by treating fish with chlortetracycline-ice has been proposed by Dolman (1957).

In Japan, almost all of the outbreaks of human botulism have resulted from consumption of "izushi", which is a preserved foodstuff consisting of raw fish, vegetables, and cooked rice. Investigation for prolonging storage life of fish with antibiotics has been carried out and practical application of chlortetracycline has been approved in some countries including Japan. The purpose of the present study is to investigate the possibility of preventing the "izushi"-borne, type E botulism by treating fish with antibiotics.

This paper deals with some experiments with oxytetracycline in culture media and also in fish with spores of a strain of $\mathrm{Cl}$. botulinum type $\mathrm{E}$.

\section{MATERIALS AND METHODS}

Antibiotic and activity assay: Oxytetracycline (OTC) used for the experiments was Biostat GP (Chas. Pfizer \& Co., Inc.). The OTC solutions were filtered through a sterilizing filter pad before addition to the culture media. The antibiotic activity was measured microbiologically by the paper pad plate method according to Tomiyama et al. (1957) using spores of B. cereus var. mycoides (ATCC 9634), PCI \#213 as the test organisms. The samples from fish were taken directly by placing the paper pad discs (Carl Schleicher \& Schuell Co.) on the surface of fish skin or in fish emulsion in a $0.1 \mathrm{M}$ citrate buffer of $\mathrm{pH} 5.2$. The standard curves for inhibition zones were drawn against oxytetracycline hydrochloride (Pfizer Taito Co., Ltd.). The activity was expressed in terms of OTC equivalent.

Inoculum of $\mathrm{Cl}$. botulinum type $\mathrm{E}$ : A type $\mathrm{E}$ strain, Tenno, isolated by Sakaguchi et al. (1954), was grown in 0.5 per cent dextrose beef liver infusion broth for 10 days at $30^{\circ} \mathrm{C}$. The organisms were centrifuged down and washed three times with $0.05 \mathrm{M}$ acetate buffer of $\mathrm{pH} 6.0$ and resuspended in the same buffer. The suspension was treated by heating at $60^{\circ} \mathrm{C}$ for 60 minutes. and stored in a refrigerator. The spore concentration was determined from the Most Probable Number as counted by culturing the decimal dilutions of a suspension in tubes ( 5 for each dilution) of brain heart infusion (Difco) at $30^{\circ} \mathrm{C}$ for 7 days.

Culture media: The brain heart infusion contains $3.7 \mathrm{~g}$ of brain heart infusion powder (Difco), $0.3 \mathrm{~g}$ of supplemented dextrose, and $0.05 \mathrm{~g}$ of sodium thioglycollate per $100 \mathrm{cc}$.

阪口玄二・阪口澄子・河端俊治・中村友光子・赤野多恵子・城水君子（国立予防衛生研究所 食品衛 生部) 
The fish homogenate was prepared by adding $100 \mathrm{cc}$ of distilled water to $100 \mathrm{~g}$ of fresh flounder (Kareius bicoloratus (B.)) muscle and by homogenizing the mixture thoroughly with a blendor.

Determination of bacterial growth: The bacterial growth was determined either nepherometrically or by measuring protein value of the bacterial cells separated by centrifugation. After treating a cell suspension with an equal amount of $1 \mathrm{~N} \mathrm{NaOH}$ solution in a boiling water bath for 10 minutes, protein value was determined colorimetrically with Folin phenol reagent according to Lowry et al. (1951) and expressed in terms of albumin equivalent.

Determination of toxin potency: The developed toxin was analyzed before and after activation. Activation was performed by mixing an aliquot of either culture supernatant, cell suspension, whole culture in fish muscle homogenate, or minced fish muscle emulsion with an equal amount of 2.0 per cent trypsin (Merck) solution in $0.05 \mathrm{M}$ acetate buffer of $\mathrm{pH} 6.0$ and incubating the mixtures at $37^{\circ} \mathrm{C}$ for 60 minutes (Duff et al., 1956).

Minimal lethal doses (MLD) were determined by intraperitoneal injection into mice with the clarified materials. The assay method was detailed in a separate paper (Sakaguchi and Sakaguchi, 1959). The specificity of toxin in fish homogenate and in fish muscles was checked by simultaneous injection with a type $\mathrm{E}$ antitoxic immune serum.

Freshness tests of fish material: Determinations of $\mathrm{pH}$ values were made on the supernatant of fish homogenate cultures and on the water extract of fish muscle with a Beckmann $\mathrm{pH}$ meter (model G).

Ammonium nitrogen was determined by a combination of Conway's microdiffusion method and neslerization of the trichloracetic acid extract of the samples (Kawabata, 1955).

\section{EXPERIMENTAL RESULTS}

\section{Effect of OTC upon Growth and Toxin Production in Brain Heart Infusion}

One half $\mathrm{cc}$ of a spore suspension of the "Tenno" strain $\left(8.0 \times 10^{4}\right.$ spores/cc) was inoculated into tubes, each of which contained $10 \mathrm{cc}$ of the brain heart infusion $(\mathrm{pH} 7.1$ ) and various quantities of OTC. The tubes were incubated at $30^{\circ} \mathrm{C}$.

All of the 32 tubes without antibiotic showed abundant growth in 24 hours. No growth took place in the tubes with $0.8 \mathrm{ppm}$ or more of OTC. Apparent growth inhibition was observed in the tubes containing $0.05 \mathrm{ppm}$ (25 positive growth out of 32), $0.1 \mathrm{ppm}$ ( 5 postive out of 16 ), or $0.2 \mathrm{ppm}$ ( 6 positive out of 32 ) of OTC.

The bacterial growth in the tubes containing the antibiotic was retarded, being only slight as compared with the control tubes.

Results of periodical determinations of $\mathrm{pH}$, bacterial protein, and toxin potencies of culture supernatant and bacterial cells are shown in Fig. 1 and Table 1.

A marked paralellism can be seen between the toxin potencies, $\mathrm{pH}$ shift, and the amount of bacterial protein. Two-tenths ppm of OTC inhibited the toxin production completely. Reduced toxin production resulted from the addition of 0.1 or $0.05 \mathrm{ppm}$ of the antibiotic.

\section{Effect of $p H$ upon the Antibacterial Action of OTC}

The same medium was adjusted to graded $\mathrm{pHs}$ in a range between $5.5-8.9$ with 1 $\mathrm{N} \mathrm{NaOH}$ or $\mathrm{HCl}$ solutions. To one half of the tubes, $0.05 \mathrm{ppm}$ of OTC was added. After seeding with the same size of the inoculum, the tubes were incubated at $30^{\circ} \mathrm{C}$ for 46 hours, at which time determinations were made in the same way.

As Tables 2 and 3 show, multiplication of the type $\mathrm{E}$ spores took place in a $\mathrm{pH}$ range between 5.9 and 8.6 in the medium used. Significant toxin potencies both in culture filtrate and in the bacterial cells were obtained in a more limited $\mathrm{pH}$ range on the 

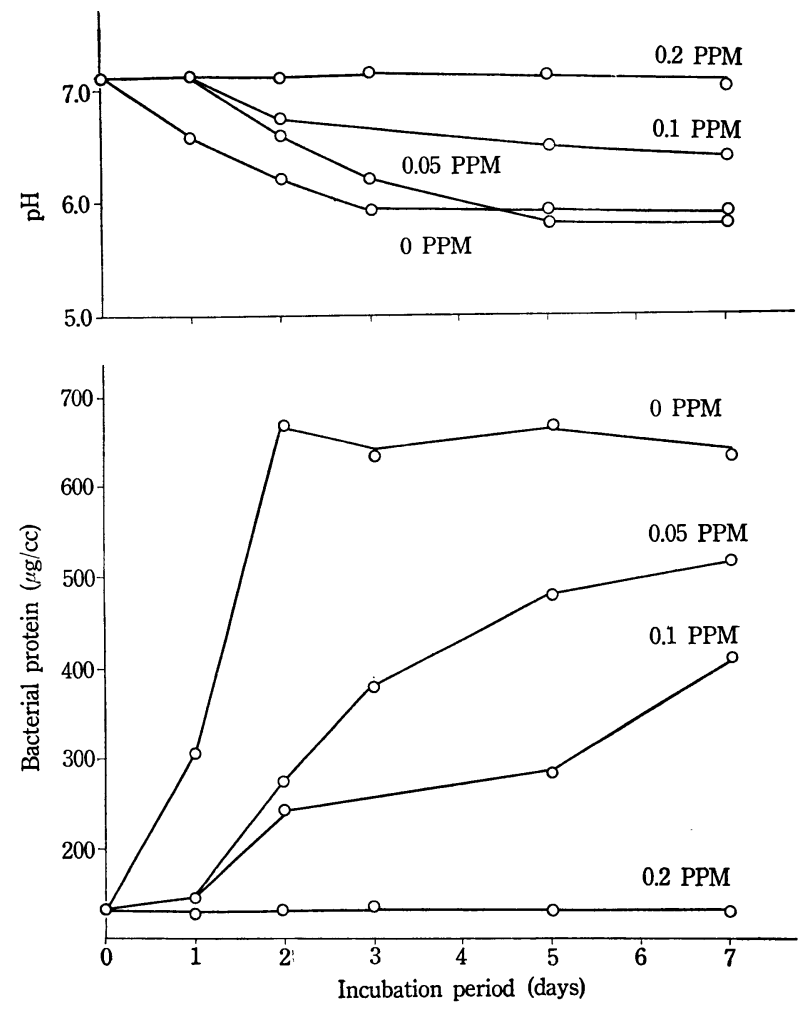

Fig. 1. Effect of OTC upon growth of type $\mathrm{E}$ Cl. botulinum in brain heart infusion at $30^{\circ} \mathrm{C}$.

acid side, where the influence of OTC was greater than on the alkaline side. At an initial $\mathrm{pH}$ of 6.9 , where the growth was most abundant, the antibiotic action of OTC was least.

\section{Effect of $\mathrm{NaCl}$ upon the Antibacterial Action of OTC}

The brain heart infusion was adjusted to $\mathrm{pH} 6.0$ to which various quantities of $\mathrm{NaCl}$ were added. The concentration of OTC used was $0.05 \mathrm{ppm}$. Inoculation, incubation, and determinations were performed in the same way as in the preceding experiment.

The results are shown in Tables 4 and 5 . As can be seen in the tables, addition of $\mathrm{NaCl}$ in one per cent or more to the medium markedly inhibited the growth and toxin production. In addition to that, the antibacterial action of $0.05 \mathrm{ppm}$ of OTC was appreciably stronger in the presence of one per cent or more of $\mathrm{NaCl}$ at $\mathrm{pH}$ 6.0.

\section{Effect of OTC upon Type E Botulinal Toxin Production in Fish Muscle Homogenate}

To $40 \mathrm{~g}$ of the fish muscle homogenate $(\mathrm{pH} 6.1-6.5)$ in a large test tube $(30 \times 200 \mathrm{~mm})$, a portion of various quantities of OTC was added and this was inoculated with $1 \times 10^{5}$ spores in one $\mathrm{cc}$ of the buffer. The tubes were incubated at $30^{\circ} \mathrm{C}$ without special care 
Table 1. Effect of OTC upon type $\mathrm{E}$ botulinal toxin production in brain heart infusion

\begin{tabular}{|c|c|c|c|c|}
\hline \multirow{3}{*}{$\begin{array}{c}\text { OTC } \\
\text { concentration }\end{array}$} & \multirow{3}{*}{$\begin{array}{l}\text { Incubation } \\
\text { period }\end{array}$} & \multicolumn{3}{|c|}{ Toxin potency } \\
\hline & & \multicolumn{2}{|c|}{ Supernatant } & \multirow{2}{*}{$\begin{array}{l}\text { Cells after } \\
\text { activation }\end{array}$} \\
\hline & & Before activation & After activation & \\
\hline \multirow[t]{5}{*}{$\begin{array}{l}\mathrm{ppm} \\
0\end{array}$} & $\begin{array}{c}\text { days } \\
1\end{array}$ & $\begin{array}{c}\mathrm{MLD} / \mathrm{cc} \\
0\end{array}$ & $\begin{array}{c}\mathrm{MLD} / \mathrm{cc} \\
0\end{array}$ & $\begin{array}{c}\mathrm{MLD} / \mathrm{cc} \\
0\end{array}$ \\
\hline & 2 & 80 & 6,400 & 6,400 \\
\hline & 3 & 1,600 & 32,000 & 1,600 \\
\hline & 5 & 2,000 & 40,000 & 8,000 \\
\hline & 7 & 800 & 32,000 & 8,000 \\
\hline \multirow[t]{6}{*}{0.05} & 1 & 0 & 0 & 0 \\
\hline & 2 & 0 & 16 & 40 \\
\hline & 3 & 0 & 160 & 160 \\
\hline & 5 & 40 & 3,200 & 4,000 \\
\hline & 7 & 80 & 8,000 & 4,000 \\
\hline & 9 & 200 & 8,000 & 8,000 \\
\hline \multirow[t]{5}{*}{0.1} & 1 & 0 & - & - \\
\hline & 2 & 0 & - & - \\
\hline & 3 & 10 & - & - \\
\hline & 5 & 80 & - & - \\
\hline & 7 & 20 & - & - \\
\hline \multirow[t]{5}{*}{0.2} & 1 & 0 & 0 & 0 \\
\hline & 2 & 0 & 0 & 0 \\
\hline & 3 & 0 & 0 & 0 \\
\hline & 5 & 0 & 0 & 0 \\
\hline & 7 & 0 & 0 & 0 \\
\hline
\end{tabular}

Table 2. Effect of OTC (0.05 ppm) upon type $\mathrm{E}$ botulinal growth in brain heart infusion of different $\mathrm{pHs}$

\begin{tabular}{cccccc}
\hline \multirow{2}{*}{ Initial $\mathrm{pH}$} & \multicolumn{3}{c}{ Control } & \multicolumn{2}{c}{$0.05 \mathrm{ppm} \mathrm{OTC}$} \\
\cline { 2 - 3 } \cline { 5 - 6 } & Final $\mathrm{pH}$ & Bacterial protein & Final $\mathrm{pH}$ & Bacterial protein \\
\hline 5.53 & 5.52 & $\mu \mathrm{g} / \mathrm{cc}$ & & 5.50 & $\mu \mathrm{g} / \mathrm{cc}$ \\
5.89 & 5.43 & 313 & & 5.58 & 0 \\
6.09 & 5.26 & 557 & & 5.53 & $(14 \%)$ \\
6.58 & 5.40 & 596 & & 5.35 & $425(23 \%)$ \\
6.93 & 5.71 & 631 & & 5.45 & $618(98 \%)$ \\
7.38 & 5.76 & 565 & & 5.76 & $502(89 \%)$ \\
7.76 & 6.05 & 469 & & 5.98 & $349(75 \%)$ \\
8.13 & 6.39 & 392 & & 6.40 & $315(80 \%)$ \\
8.57 & 6.77 & 337 & & 6.81 & $217(65 \%)$ \\
8.85 & 6.68 & 0 & 8.75 & 0 \\
\hline
\end{tabular}


Table 3. Effect of OTC (0.05 ppm) upon type $\mathrm{E}$ botulinal toxin production in brain heart Infusion of different $\mathrm{pHs}$

\begin{tabular}{|c|c|c|c|c|c|c|}
\hline \multirow{3}{*}{$\begin{array}{c}\text { Initial } \\
\mathrm{pH}\end{array}$} & \multicolumn{3}{|c|}{ Control } & \multicolumn{3}{|c|}{0.05 ppm OTC } \\
\hline & \multicolumn{2}{|c|}{ Supernatant } & \multirow{2}{*}{$\begin{array}{l}\text { Cells after } \\
\text { activation }\end{array}$} & \multicolumn{2}{|c|}{ Supernatant } & \multirow{2}{*}{$\begin{array}{l}\text { Cells after } \\
\text { activation }\end{array}$} \\
\hline & $\begin{array}{l}\text { Before } \\
\text { activation }\end{array}$ & $\begin{array}{c}\text { After } \\
\text { activation }\end{array}$ & & $\begin{array}{c}\text { Before } \\
\text { activation }\end{array}$ & $\begin{array}{c}\text { After } \\
\text { activation }\end{array}$ & \\
\hline 5.53 & $\begin{array}{c}\mathrm{MLD} / \mathrm{cc} \\
0\end{array}$ & $\begin{array}{c}\mathrm{MLD} / \mathrm{cc} \\
0\end{array}$ & $\begin{array}{c}\text { MLD/cc } \\
0\end{array}$ & $\begin{array}{c}\mathrm{MLD} / \mathrm{cc} \\
0\end{array}$ & $\begin{array}{c}\text { MLD/cc } \\
0\end{array}$ & $\begin{array}{c}\mathrm{MLD} / \mathrm{cc} \\
0\end{array}$ \\
\hline 5.89 & 16 & 4,100 & 4,100 & 0 & 64 & 260 \\
\hline 6.09 & 32 & 8,200 & 16,000 & 0 & 260 & 260 \\
\hline 6.58 & 130 & 16,000 & 16,000 & 16 & 2,000 & 4,100 \\
\hline 6.93 & 1,000 & 16,000 & 4,100 & 4 & 510 & 2,000 \\
\hline 7.38 & 4 & 1,000 & 8,200 & 8 & 510 & 650 \\
\hline 7.76 & 4 & 260 & 130 & 2 & 260 & 260 \\
\hline 8.13 & 2 & 64 & 260 & 0 & 32 & 16 \\
\hline 8.57 & 0 & 0 & 130 & 0 & 4 & 0 \\
\hline 8.85 & 0 & 0 & 0 & 0 & 0 & 0 \\
\hline
\end{tabular}

Table 4. Effect of OTC $(0.05 \mathrm{ppm})$ upon type $\mathrm{E}$ botulinal growth in brain heart infusion of $\mathrm{pH} 6.0$ added with varying dose of $\mathrm{NaCl}$

\begin{tabular}{crc}
\hline \multirow{2}{*}{$\mathrm{NaCl}$ added } & \multicolumn{2}{c}{ Bacterial protein } \\
\cline { 2 - 3 }$\%$ & Control & $0.05 \mathrm{ppm}$ OTC \\
\hline 0 & $\mu \mathrm{g} / \mathrm{cc}$ & $\mu \mathrm{g} / \mathrm{cc}$ \\
1.0 & 437 & $246(56 \%)$ \\
2.0 & 257 & $55(21 \%)$ \\
3.0 & 11 & $0 \quad(0 \%)$ \\
4.0 & 0 & 0 \\
\hline
\end{tabular}

Table 5. Effect of OTC $(0.05 \mathrm{ppm})$ upon type $\mathrm{E}$ botulinal toxin production in brain heart infusion of $\mathrm{pH} 6.0$ added with varying dose of $\mathrm{NaCl}$

\begin{tabular}{|c|c|c|c|c|c|c|}
\hline \multirow{3}{*}{$\begin{array}{l}\mathrm{NaCl} \\
\text { added }\end{array}$} & \multicolumn{3}{|c|}{ Control } & \multicolumn{3}{|c|}{$0.05 \mathrm{ppm} \mathrm{OTC}$} \\
\hline & \multicolumn{2}{|c|}{ Supernatant } & \multirow{2}{*}{$\begin{array}{l}\text { Cells after } \\
\text { activation }\end{array}$} & \multicolumn{2}{|c|}{ Supernatant } & \multirow{2}{*}{$\begin{array}{l}\text { Cells after } \\
\text { activation }\end{array}$} \\
\hline & $\begin{array}{l}\text { Before } \\
\text { activation }\end{array}$ & $\begin{array}{c}\text { After } \\
\text { activation }\end{array}$ & & $\begin{array}{c}\text { Before } \\
\text { activation }\end{array}$ & $\begin{array}{c}\text { After } \\
\text { activation }\end{array}$ & \\
\hline $\begin{array}{l}\% \\
0\end{array}$ & $\begin{array}{c}\text { MLD/cc } \\
16\end{array}$ & $\begin{array}{c}\text { MLD/cc } \\
8,200\end{array}$ & $\begin{array}{l}\text { MLD/cc } \\
16,000\end{array}$ & $\begin{array}{c}\mathrm{MLD} / \mathrm{cc} \\
0\end{array}$ & $\begin{array}{l}\text { MLD/cc } \\
260\end{array}$ & $\begin{array}{l}\text { MLD/cc } \\
510\end{array}$ \\
\hline 1.0 & 16 & 1,000 & 2,000 & 0 & 64 & 16 \\
\hline 2.0 & 0 & 0 & 0 & 0 & 0 & 0 \\
\hline 3.0 & 0 & 0 & 0 & 0 & 0 & 0 \\
\hline 4.0 & 0 & 0 & 0 & 0 & 0 & 0 \\
\hline
\end{tabular}


Table 6. Effect of OTC upon type E botulinal toxin production in fish homogenate

\begin{tabular}{|c|c|c|c|c|c|}
\hline \multirow{2}{*}{$\begin{array}{l}\text { OTC } \\
\text { conc. }\end{array}$} & \multirow{2}{*}{ Incubation period } & \multirow{2}{*}{$\mathrm{pH}$} & \multirow{2}{*}{$\mathrm{NH}_{3}-\mathrm{N}$} & \multicolumn{2}{|c|}{ Toxin potency } \\
\hline & & & & Before activation & After activation \\
\hline \multirow[t]{4}{*}{$\begin{array}{l}\text { ppm } \\
0\end{array}$} & $\begin{array}{c}\text { days } \\
0\end{array}$ & 6.47 & $\begin{array}{r}\mathrm{mg} \% \\
7\end{array}$ & $\mathrm{MLD} / \mathrm{g}$ & MLD/g \\
\hline & 2 & 6.50 & 208 & 1,000 & 2,000 \\
\hline & 5 & 6.88 & 683 & 4,100 & 32 \\
\hline & 8 & 7.10 & 975 & 32 & 32 \\
\hline \multirow[t]{4}{*}{0.05} & 0 & 6.47 & 7 & - & - \\
\hline & 2 & 6.22 & 94 & 64 & 16 \\
\hline & 5 & 6.82 & 546 & 1,000 & 32 \\
\hline & 8 & 7.19 & 500 & 32 & 16 \\
\hline \multirow[t]{4}{*}{0.2} & 0 & 6.11 & 12 & - & - \\
\hline & 2 & 6.95 & 156 & 16 & 8 \\
\hline & 4 & 7.12 & 585 & 0 & 0 \\
\hline & 6 & 7.16 & 1,150 & 0 & 0 \\
\hline \multirow[t]{4}{*}{0.2} & 0 & 6.11 & 12 & - & - \\
\hline & 2 & 6.92 & 134 & 8 & 32 \\
\hline & 4 & 7.13 & 635 & 0 & 0 \\
\hline & 6 & 7.22 & 845 & 0 & 0 \\
\hline
\end{tabular}

for anaerobiosis. Toxin potencies before and after treating with 1.0 per cent trypsin, $\mathrm{pH}$ values, and ammonium nitrogen were determined periodically with the samples taken from dual cultures.

As Table 6 shows, type $\mathrm{E}$ spores seeded into fish muscle homogenate germinated and multiplied rapidly with formation of a considerable amount of toxin at $30^{\circ} \mathrm{C}$. Putrefaction of the homogenate was also very rapid releasing a large quantity of ammonium nitrogen. The largest concentration of OTC tested $(0.2 \mathrm{ppm})$ had no visible effect upon keeping the homogenate from deterioration, yet the addition of $0.1 \mathrm{ppm}$ or more of OTC prevented the botulinal toxin production to a very great extent. As is apparent from the table, type $\mathrm{E}$ toxin production in the fish homogenate is characterized by relatively small activation ratio and the rapid detoxification of the formed toxin. At an early stage (the 2nd day), treatment of the botulogenic homogenate with trypsin increased the toxicity, whereas later it decreased the toxicity. These results indicate the occurrence of spontaneous activation of the toxin precursor and the decomposition of the formed toxin possibly by proteolytic actions originated from putrefactive microorganisms.

\section{Toxin Production of Type E Cl. Botulinum in Fish Treated with OTC}

Fresh, gutted "karei" (Kareius bicoloratus (B.)) weighing 200-550 g were dipped in OTC solution of the indicated concentrations for 10 or 120 minutes at room temperature. Then each fish was inoculated with $2.0 \mathrm{cc}$ of a type E spore suspension $\left(5.4 \times 10^{5}\right.$ spores/ 
cc) into deep muscle at five sites along the vertebra. Two fish were put together in a polyethylene bag. One group of the fish was stored in a cold room $\left(4 \pm 2{ }^{\circ} \mathrm{C}\right)$ and the other at room temperature $\left(20 \pm 0.5^{\circ} \mathrm{C}\right)$.

A sample of $5.0 \mathrm{~g}$ of muscle from each of two fish was taken, and ground with a mortar and pestle with the aid of fine quartz. Twenty cc of a $0.1 \mathrm{M}$ citrate buffer $(\mathrm{pH}$ 5.2) was added to $10 \mathrm{~g}$ of the minced fish muscle. After taking samples for antibiotic assay, $20 \mathrm{cc}$ of distilled water was added to the emulsion to make the final dilution factor of 5 , with which determinations were made.

As summarized in Table 7, the storage life of the fish treated with OTC was apparently prolonged as judged by $\mathrm{NH}_{3}-\mathrm{N}$ or $\mathrm{pH}$ values. Storage at cold temperature aided the effect of the antibiotic.

The type $\mathrm{E}$ spores inoculated into fish muscle of the control group germinated and multiplied with formation of toxin to a considerably high level in 5 days at $20^{\circ} \mathrm{C}$. A certain degree of inhibition in toxin production was seen in the fish treated with OTC. Larger activation ratios were obtained in the fish treated with OTC than those in control fish.

Even at a temperature down to $4^{\circ} \mathrm{C}$, an appreciable potency of toxin was detected

Table 7. Type $\mathrm{E}$ botulinal toxin production in the fish treated with OTC

\begin{tabular}{|c|c|c|c|c|c|c|c|}
\hline \multirow[b]{2}{*}{ OTC treatment } & \multirow{2}{*}{$\begin{array}{l}\text { Storage } \\
\text { period }\end{array}$} & \multirow[b]{2}{*}{$\mathrm{pH}$} & \multirow[b]{2}{*}{$\mathrm{NH}_{3}-\mathrm{N}$} & \multicolumn{2}{|c|}{ OTC residue } & \multicolumn{2}{|c|}{ Toxin potency } \\
\hline & & & & Skin & Muscle & $\begin{array}{l}\text { Before } \\
\text { activation }\end{array}$ & $\underset{\text { activation }}{\text { After }}$ \\
\hline \multicolumn{8}{|l|}{ Stored at $20^{\circ} \mathrm{C}$} \\
\hline \multirow[t]{4}{*}{ Control } & $\begin{array}{c}\text { days } \\
0\end{array}$ & 6.71 & $\begin{array}{c}\mathrm{mg} \% \\
14.6\end{array}$ & $\begin{array}{l}\text { ppm } \\
0.26^{*}\end{array}$ & $\underset{0^{* *}}{\mathrm{ppm}}$ & $\mathrm{MLD} / \mathrm{g}$ & $\mathrm{MLD} / \mathrm{g}$ \\
\hline & 2 & 6.50 & 16.2 & $0.27^{*}$ & 0 & 0 & 0 \\
\hline & 5 & 7.08 & 347 & $0.18^{*}$ & 0 & 320 & 10,000 \\
\hline & 7 & 7.68 & 557 & 0 & 0 & 1,300 & 20,000 \\
\hline \multirow{4}{*}{$\begin{array}{l}\text { Dipped in } 30 \mathrm{ppm} \\
\text { solutionfor } \\
120 \mathrm{~min} .\end{array}$} & 0 & 6.60 & 16.2 & 10.0 & 0 & - & - \\
\hline & 2 & 6.42 & 18.0 & 3.26 & 0 & 0 & 0 \\
\hline & 5 & 6.91 & 18.6 & 0.84 & 0 & 0 & 2,600 \\
\hline & 7 & 6.54 & 86.3 & 1.17 & 0.26 & 80 & 2,600 \\
\hline \multicolumn{8}{|l|}{ Stored at $4^{\circ} \mathrm{C}$} \\
\hline \multirow[t]{5}{*}{ Control } & 0 & 6.71 & 17.8 & $0.30^{*}$ & 0 & - & - \\
\hline & 6 & 6.40 & 19.7 & $0.26^{*}$ & 0 & 0 & 0 \\
\hline & 10 & 6.60 & 27.4 & $0.43^{*}$ & 0 & 0 & 0 \\
\hline & 14 & 6.60 & 34.9 & $0.16^{*}$ & 0 & 0 & 0 \\
\hline & 21 & 6.90 & 106 & 0 & 0 & 0 & 160 \\
\hline \multirow{5}{*}{$\begin{array}{l}\text { Dipped in } 10 \mathrm{ppm} \\
\text { solution for } \\
10 \mathrm{~min} .\end{array}$} & 0 & 6.54 & 17.6 & 5.49 & 0 & - & - \\
\hline & 6 & 6.61 & 19.6 & 1.15 & 0 & 0 & 0 \\
\hline & 10 & 6.50 & 17.1 & 0.44 & 0 & 0 & 0 \\
\hline & 14 & 6.72 & 23.9 & 0.16 & 0 & 0 & 0 \\
\hline & 21 & 6.78 & 39.9 & 0.17 & 0 & 0 & 0 \\
\hline
\end{tabular}

* Non-specific inhibition zones were presented in OTC equivalent.

** 0 indicates less than $0.15 \mathrm{ppm}$, the lowest detectable activity. 
through trypsinization of the 21 days' sample of the control fish. Although no residual antibiotic activity was detected in the muscle of fish dipped in $10 \mathrm{ppm}$ of OTC for 10 minutes, there was no sign of multiplication of the type $\mathrm{E}$ spores. The residual antibiotic activity of skin dropped rapidly in the early stage, but there was no indication that the disappearance was the result of penetration into the muscle.

\section{Discussion}

Although a slight multiplication of type $\mathrm{E}$ botulinal spores may occur in some tubes of brain heart infusion (Difco) containing $0.2 \mathrm{ppm}$ of OTC, the concentration seems enough to inhibit the formation of toxin. Inhibition of the growth and the formation of toxin was also demonstrated with 0.1 and $0.05 \mathrm{ppm}$ of OTC in the medium. It is interesting that the antibiotic not only delays the bacterial growth and the formation of toxin, but also lowers the maximum yield of bacterial protein and the toxin. The fact suggests that OTC may work bacteriocidally upon type $E$ botulinal organisms after germination. Besides, it has been demonstrated that OTC in the brain heart infusion is inactivated at $30^{\circ} \mathrm{C}$ with a first order constant of $0.63\left(\right.$ day $\left.^{-1}\right)$ (the corresponding figure for CTC is 1.97). It is still unknown why any survival spores do not multiply when the OTC activity becomes undetectable in the medium.

The results described in this paper have reconfirmed the necessity of activation of type $\mathrm{E}$ botulinal toxin in assaying, since the rate of spontaneous activation is markedly influenced by many factors. There seems to be no reason to doubt that the potential hazard may reside in the amount of the toxin precursor rather than in that of the spontaneously activated toxin. It has also been reconfirmed that the total potency of type $\mathrm{E}$ toxin is dependent upon the amount of bacterial cells when the growing conditions are the same. It can be said that the inhibitory action of OTC upon type E botulinal toxin production is the results of the growth inhibition.

Antibacterial action of OTC is influenced by $\mathrm{pH}$ of the medium. OTC may be more effective at acid reaction, where type $\mathrm{E}$ toxin production is more facilitated, a smaller amount of toxin precursor is liberated from the bacterial cells, and usually a larger activation ratio is obtained in assay. A plausible explanation for these results is that the enzymes associated with liberation and activation of the toxin precursor as well as those associated with inactivation of the formed toxin are less active at acid reaction.

Addition of sodium chloride in one per cent or more to the brain heart infusion enhanced the antibacterial action of OTC upon type $\mathrm{E}$ botulinal organisms, which implies the possibility that a combination of $\mathrm{NaCl}$ and OTC could be more favorably used in control of type E botulism.

Apparent inhibition of the type $\mathrm{E}$ toxin production in fish muscle homogenate was observed in response to the concentration of OTC added. The activation ratios were very small and decomposition of the toxic activity was very rapid with the cultures in fish muscle homogenate. These may have resulted from the proteolytic activity of the putrefactive microorganisms. As a matter of fact, putrefaction of the homogenate was very rapid.

No particular inhibition of the toxin production in the whole fish treated with OTC was demonstrated, as compard with the hemogenate. There may have been many factors which varied the effect of OTC treatment. The storage temperature, penetration of OTC, and its decomposition may be part of such important factors. In fact, the treatment of 
gutted fish by dipping them in $10 \mathrm{ppm}$ OTC solution for 10 minutes inhibited the production of toxin in fish inoculated with one million of type $\mathrm{E}$ spores in three weeks under refrigeration. The same treatment had no visible effect when the fish were kept at room temperature. As stated before, "izushi" is generally preserved in a sort of pickle for three weeks or longer, so it is important that the antibiotic to be added is stable. In this regard, OCT may be more suitable than CTC. No appreciable decrease in activity occurred when OTC solutions were kept at $11^{\circ} \mathrm{C}$ in a phosphate buffer of either $\mathrm{pH} 6$, 7, or 8 (Kawabata et al., 1960 b). The point, therefore, is to make the antibiotic penetrate into the deep inside part of fish muscle to reach a level of $0.2 \mathrm{ppm}$ or more, where type $\mathrm{E}$ botulinal toxin production may be completely inhibited as the present study demonstrates.

Comparatively large activation ratios were obtained with the fish muscle, especially with those treated with the antibiotic, as compared with fish muscle homogenate. It may have been partly due to the difference in bacterial flora. In the fish muscle treated with OTC, resistant organisms are predominant. They are usually nonputrefactive (Kawabata et al., 1960a). Therefore, spontaneous activation of type $\mathrm{E}$ toxin may be less in those fish. The lower temperatures at which the fish experiment were conducted may have been one of the factors. At $4^{\circ} \mathrm{C}$, toxin was demonstrated only through activation in a period of three weeks. $\mathrm{PH}$ shift as a result of metabolic activity of the microbial flora may also have been one of the factors in regard to the stability of the toxin precursor and the activated toxin.

In any event, type $\mathrm{E}$ botulinal organisms seem to be very sensitive to OTC. Practical application of the antibiotic to prevent a particular disease, fish-borne, type $\mathrm{E}$ botulism, may be worthwhile to be considered further.

\section{SUMMARY}

Effect of OTC upon toxin production of $\mathrm{Cl}$. botulinum type $\mathrm{E}$ in culture media, in fish muscle homogenate, and in fish muscle was studied. Toxin potencies were analyzed before and after trypsinization of materials.

1. Toxin production does not take place in the brain heart infusion containing $0.2 \mathrm{ppm}$ of $\mathrm{OTC}$ at $30^{\circ} \mathrm{C}$ and it is appareciably lessened by 0.1 or $0.05 \mathrm{ppm}$ of OTC.

2. The antibiotic action of OTC is more effective at the acid side, where toxin production of type $\mathrm{E} \mathrm{Cl}$. botulinum is more facilitated.

3. Addition of sodium chloride in one per cent or more to the brain heart infusion of $\mathrm{pH} 6.0$ enhances the effect of OTC.

4. In fish muscle homogenate, OTC is as effective as in the culture medium. The type $\mathrm{E}$ toxin produced in fish muscle homogenate is likely to be activated more easily and destroyed more rapidly, probably due to the proteolytic action of contaminating putrefactive microorganisms.

5. Treatment of fish by dipping in OTC solution lessens the amount of the botulinal toxin produced by the type $\mathrm{E}$ spores inoculated into the muscle. It is essential to store the fish at a cold temperature to minimize the botulinal toxin production. Other factors possibly associated with minimizing the type $\mathrm{E}$ toxin formation have been discussed.

The authors wish to thank the Chas Pfizer and Co. and the Pfizer Taito Co., Ltd. for a research grant for the present study and for providing the antibiotics. 


\section{REFERENCES}

Boyd, J. W., Bluhm, H. M., Muirhead, C. R. (1956): Use of antibiotics for the preservation of fish and sea food. Am. J. Pub. Health, 46, 1531-1539.

Dolman, C. E. (1957): Type E (fish-borne) botulism. Jap. J. M. Sc. \& Biol., 10, 383-395.

DufF, J. T., Wright, G. G. \& YARINSKY, A. (1956): Activation of Clostridium botulinum type $\mathrm{E}$ toxin by trypsin. J. Bact., 72, 455-460.

KAWABATA, T. (1955): Micro-analytical methods for $\mathrm{NH}_{3}-\mathrm{N}$, TMA-N and TMAO-N. Sendo Hoji Renraku Kenkyu-han Jyoho, No. 8, 1-12 (text in Japanese).

Kawabata, T., Sakaguchi, G., Sakaguchi, S., Nakamura, Y., Akano, T. \& Okitsu, T. (1960a): Role of oxyteracycline on keeping the quality of fish with special reference to increase of resistant bacterial population. Bull. Jap. Soc. Sc. Fish., 26, 300-311.

Kawabata, T., Sakaguchi, G., Nakamura, Y. \& AKano, T. (1960b) : Factors affecting the decomposition of oxytetracycline and chlortetracycline. J. Antibiotics, 13, in press.

Lowry, O. H., Rosebrough, N. J., FARR, A. L. \& Randall, R. J. (1951). Protein measurement with the Folin phenol reagent. J. Biol. Chem., 193, 265-275.

Sakaguchi, G., Tohyama, Y., Saito, S., Fujisawa, S. \& Wada, A. (1954) : An outbreak of type E botulism in Akita Prefecture due to gilthead-izushi. Jap. J. M. Sc. \& Biol., 7, 539546.

SAKAGUCHI, G. \& SAKAGUCHI, S. (1959): Studies on toxin production of Clostridium botulinum type E. III. Characterization of toxin precursor. J. Bact., 78, 1-9.

TomiYama, T., TsudA, A. \& Yone, Y. (1957): An improved method for pad plate microbiologic assay of chlortetracycline (CTC) in tissues. Bull. Jap. Soc. Sc. Fish., 23, 660-670 (text in Japanese). 